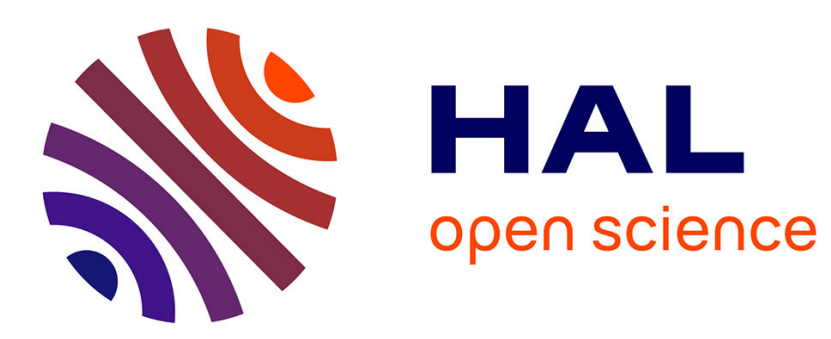

\title{
The 'social' in the institutionalisation of local cultural policies in France and Germany
}

Vincent Dubois, Pascale Laborier

\section{To cite this version:}

Vincent Dubois, Pascale Laborier. The 'social' in the institutionalisation of local cultural policies in France and Germany. International Journal of Cultural Policy, 2003, French and German Cultural Policies, 9 (2), pp.195-206. 10.1080/1028663032000119233 . halshs-00130985

\section{HAL Id: halshs-00130985 https://shs.hal.science/halshs-00130985}

Submitted on 16 Feb 2020

HAL is a multi-disciplinary open access archive for the deposit and dissemination of scientific research documents, whether they are published or not. The documents may come from teaching and research institutions in France or abroad, or from public or private research centers.
L'archive ouverte pluridisciplinaire HAL, est destinée au dépôt et à la diffusion de documents scientifiques de niveau recherche, publiés ou non, émanant des établissements d'enseignement et de recherche français ou étrangers, des laboratoires publics ou privés. 


\title{
THE ‘SOCIAL’ IN THE INSTITUTIONALISATION OF LOCAL CULTURAL POLICIES IN FRANCE AND GERMANY
}

\author{
Vincent Dubois and Pascale Laborier \\ International Journal of Cultural Policy, 9 (2), 2003, p. 195-206.
}

Can one produce an international comparison of cultural policies, and if so, how? These are our initial questions. The possibility of a comparative approach appears as a particular problem in France, where the thesis positing the very existence of cultural policies amalgamated with the existence of a ministry for culture - as nationally specific enjoys a broad consensus, thereby depriving any comparative analysis of an object. Whether it is celebrated or denounced, ${ }^{i}$ the 'French exception' is scarcely questioned. Furthermore, the 'French model' has become the object of an export drive, as is shown by the occupation by agents from the Ministry of Culture of positions in international institutions (Unesco, the Council of Europe), the recent organisation of the 'Malraux colloquia' whose vocation is the diffusion of this 'unique model' across the world, and even the references in other countries to this supposed 'model'. ii

Against this flat refusal of any comparative approach, seeing no foreign cases for comparison, one can set - notably in the framework of specialised international organisations - the juxtaposition of national monograph studies that presuppose a common identity for objects presented as equivalent. This was the case, for example, with the programme of studies launched by Unesco in the 1970s and 1980s, which gave rise to the publication of some sixty brochures on 'cultural policies'. The more recent programme for the evaluation of national cultural policies developed by the Council of Europe also puts side by side situations whose homogeneity, to say the least, is not an a priori given (from Sweden at the end of the 1980 s to the Eastern European countries ten years later). The seemingly intractable question of the standardisation of indicators for evaluation is, moreover, itself a good indication of the problematic character of such homogenisation (see Gray, 1996).

Absolute national specificities on the one hand, indiscriminate generalisations on the other hand: for opposite reasons, these two postures divert attention from what could constitute a true comparison. To move beyond this impasse, a comparative approach must not, as it seems to us, focus on 'things' conceived as the distinct manifestations of a common essence (cultural policies in France and Germany), but rather on processes, namely the construction of the categories of public intervention in cultural matters. ${ }^{\text {iii }}$ The object of comparison then becomes the way in which domains of action are divided up; the aggregation of objects and practices of intervention which are thereby brought together and conceptualised conjointly; the production of principles bringing elements to cohere that in other times and places would be considered separately. In other words, the point of this article is not so much to compare the conduct of cultural policies whose form might be seen as identical from one country to another, but rather, precisely, to confront in the two cases under consideration the work that gave these policies their form, and through which the policies were presented and given meaning.

Let us initially recall the principal characteristics of this policy-forming process. In France, the Ministry of Cultural Affairs, created in 1959, established itself by marking itself off from neighbouring categories of public intervention, such as popular education, leisure, or later sociocultural animation. This process of institutionalisation through differentiation can be seen equally at the level of local authorities, who gradually equipped themselves with 
specifically cultural administrative structures, separating these from larger groupings departments for sports and fine arts, animation, youth, etc. - which previously had been able to integrate the elements constituting local action for culture. French cultural policies, whether local or national, thus assumed their identity through a work of classification that emancipated them from more general categories (such as, notably, sociocultural animation). Kulturpolitik in the Federal Republic of Germany, developed at the level of the regions and municipalities, brings together not simply the cultural sector in the narrow sense of the fine arts and cultural institutions, but sometimes also education, even if the institutionalisation of cultural policies took place here, as in France, through a differenciation with regard to other sectors of intervention.

In order to account for these differenciated processes of categorisation and formation, we have chosen to focus on what, both in France and Germany, has been and continues to be problematic: the insertion of the public treatment of culture in a social context. For it is here that comes into play, among other things, the question of the definition of the type of culture for which intervention is appropriate (legitimate, popular, subversive...) (see Passeron, 1991). Equally, it is here that come into play the principles giving legitimacy to those agents that intervene: the social competence of the animateur, the political vision of the engaged artist, or the technical expertise of the cultural manager. It is in the formation and questioning of such loose and intermediary categories ('socioculturel' in French, 'Soziokultur' in German) that we can observe most clearly the moves to cross and mark frontiers constituting that work of categorisation we wish to study.

In the 1960s and 1970s, new forms of public treatment of culture were invented, characterized by a strong anchoring in local areas, the involvement of activists, and a deliberate distancing of legitimate culture. This was sociocultural animation in France, and Soziokultur in the FRG. The agents and points of reference associated with these movements, although playing a not inconsiderable role in the formation of public intervention in culture at a local level, were generally sidelined as this policy developed. New agents, laying claim to cultural expertise and referring to a body of professional knowledge, organised, especially from the mid-1980s onwards, the relegation of these 'pioneers', brought down to the rank of amateurs or activists, full of good will but with only limited professional competence. Some of the themes characterising those older forms of policy have nevertheless resurfaced over recent years. It is by laying claim to a new type of expertise, this time linked to their knowledge of the 'terrain' and to the 'cultural' management of the social and urban crises, that the professionals of local cultural policies have been reoccupying problematics against which they had previously constructed their identities and established their positions.

What were the conditions for the invention, in France and Germany in the 1960s and 1970 s, of forms of treatment of culture structured around explicitly 'social' objectives? What position do these forms occupy in the development of public intervention in culture at a local level? Finally, what are the logics presiding over the relegation and then the partial rediscovery of these modes of intervention? It is around these questions that we would like to provide some elements of comparison between the French and German cases. Besides confronting different modes of categorisation of local public policy in different places and times, reviewing these transformations will enable us also to shed light on the different forms of expertise in play at a local level: from the disparagement of expertise in the name of activism and proximity to the social 'terrain', to the moves laying claim to a professionalism associated with the constitution at a national level of a body of 'cultural mediators', to, finally, the invention of new types of know-how and professional positions at the interface between the social and the cultural, tied to an 'expert' understanding - i.e. mediated by technical procedures and specialised forms of knowledge - of the local terrain. 


\section{SOCIOCULTURAL, SOZIOKULTUR: SOCIAL MOBILISATIONS AND CULTURAL INNOVATIONS}

Following the manifold local initiatives of the 1960s, and after the processes of mobilisation issuing from the contestatory movements of the end of the decade, new kinds of relation to culture were invented both in France and the Federal Republic of Germany, locally situated and detached from the 'dominant' culture. Sociocultural animation in France and Soziokultur in Germany enabled in different ways the diverse networks of associations and activists to form coherent groupings, followed by the institutionalisation of a new category of public intervention.

In both countries, suburban districts and urban areas in general, at different times and following different rhythms from case to case, often constituted the sites of powerful social mobilisations around cultural issues. In the 1960s and 1970s, the most visible form of these was the mobilisation and investment of the middle classes in the communitarian and civic utopias of sociocultural animation. ${ }^{\text {iv }}$ This localised production of cultural life was strongly marked by the local and social identities it symbolised. Suburban cultural action was thus inextricably enmeshed in the general sphere of social relations.

The social insertion of cultural policies nevertheless took place in different manners in the two countries. The social effects of cultural action oscillate between 'integration and subversion' (Gaudibert, 1972), and one might schematically associate developments in France with the first term of this opposition, while developments in Germany can be considered as coming closer to the second term.

Social integration through local cultural action

In France, the task of inserting cultural policies into social contexts fell to the constellation of post-war popular education groups (such as People and Culture or the Federation of Houses for Youth and Culture). ${ }^{\mathrm{v}}$ It was also carried out with the support of local politicians, notably but not exclusively from the Left. Thus 1960 saw the creation in France of the National Federation of Local Cultural Centres (FNCCC - Fédération nationale des centres culturels communaux), which defended an alternative model of cultural action to that propounded by the new Ministry for Cultural Affairs. The local politicians and animateurs affiliated to the FNCCC advocated a cultural policy closely related to local associations and looking to promote forms of local sociability (collective outings, amateur practices...) that were supposed to organise around the municipality a stronger sense of social cohesion. Their 'experience of the local terrain' was put forward to counter the 'theory' of ministerial experts denounced as 'gurus' and 'technocrats' (see Dubois, 1995; Urfalino, 1994).

Communist local politicians participated in this type of mobilisation, but did not bring with them the discourses of revolution or working-class autonomy, since these had been officially abandoned by the Central Committee meeting at Argenteuil in 1966 (see Lambert and Matonti, 1998). Certains elements of the 'New Left' were also present in these processes of mobilisation, without for all that bringing with them any kind of cultural radicalism.

Overall, while 'the social functions of culture', to use the typical vocabulary of the time, were constituted as a suitable issue for politicisation, they were hardly conceptualised with reference to the supposedly 'subversive' virtues of artistic creation. More stress was placed instead on intermediary and not exclusively artistic forms of culture (festivals, carnivals, extracurricular acitivities...) whose promotion was envisaged as a 'soft' way of managing 
social problems: the improvement of the urban environment, efforts to make the new urban estates more human, etc.

A more radical politicisation: Soziokultur in the Federal Republic of Germany

This politicisation takes on a more subversive aspect in the Federal Republic of Germany, where the promoters of Soziokultur at the end of the 1960s base their work more than French animateurs on politically committed forms of art (see Laborier, 1998). It originates in the radical denunciation of traditional cultural institutions by activists of a so-called 'alternative' culture, coming both from small extreme-left groupings and also from the new social movements. Intellectuals and politically committed artists, such as Peter Weiss or Josef Beuys, became the heralds of this culture of 'resistance'. The culture promoted by this 'critical' new left and the social movements included initiatives undertaken in urban districts to bring art out of the museums, as well as avant-garde artistic expression as a whole. To some extent, the sociocultural programmes also pursued the goal of rehabilitating and respecting the cultural practices of certain 'minorities', whether understood in 'ethnic', sexual, social or religious terms. The aesthetisication of everyday life was thus based on a 'multicultural' approach.

Soziokultur was thus originally fostered by the 'alternative' elements of the new left. Their challenge to the legitimacy of the State attracted a myriad of movements with a sociocultural vocation, forming so many composite intermediaries that would over the 1980s inflect the content of cultural policies under socialist municipal councils, by successfully claiming subsidies for their community projects.

\section{THE INSTITUTIONALISATION OF NEW CATEGORIES OF ACTION}

These processes of mobilisation were to a large extent, in France as in Germany, at the origin of the development of local cultural policies, in particular in suburban districts. In fact, they were followed by a twofold movement, professionalising and dividing up a sector progressively specified as 'cultural', to the extent that its designation gradually shed the prefix 'socio'. This transition from multiform mobilisations evolving out of given circumstances to more compartmentalised local policies inscribed in established institutions and positions was not self-evident. For how are activist engagements converted into professional positions? How does one maintain a role of social intermediary while at the same time developing a cultural specialisation? The transformation was all the more problematic since, as well as their professional conversion, it also led to the relegation of agents and discourses that had promoted the very development of these policies.

\section{Contradictions generated by a process of institutionalisation}

The distinctive attribute of the anti-institutional movements, whose promoters campaigned for a break with preestablished categories, was to be brought up finally against a choice between disappearing and giving up on their original project. They could disappear when the initial activist engagement lost impetus; or they could give up on their initial principles when these groups became institutionalised, when wide-ranging forms of intervention became just one compartmentalised sector of activity, and when personal engagement gave way to professional positioning. From the 1970s in France, the development 
of the 'sociocultural' sector was accompanied by a form of renunciation; in the Federal Republic of Germany, this was less pronounced and, above all, occured only later.

Firstly, community-based forms of mobilisation were progressively municipalised. The themes of 'citizen participation' and 'improved cohabitation' developed in France thanks to the fostering of cultural programs in 'pioneering' cities from the middle of the 1960s onwards (notably in Grenoble and Rennes), and then very extensively after the muncipal elections of 1971 and 1977, which brought left-wing non-communist activists into municipal councils.

In the Federal Republic of Germany, politicians and intellectuals close to the German Socialist Party (SPD) or left-wing trades union organisations very rapidly set in motion, albeit in a euphemistic manner, the dynamic of institutionalisation, in groups for consultation and evaluation such as the Council of German Cities (Deutscher Städtetag) or the Society for Cultural Policy (Kulturpolitische Gesellschaft). Emphasis was placed largely on intermediary forms of culture, the improvement of the 'living environment' and on the 'humanisation' of new urban estates, as in France, as well as on defending more generally a 'culture of daily life' for all.

The institutionalisation of socioculture in socialist regional governments or municipal authorities, as in the city of Frankfurt or the city-states of Berlin, Bremen and Hamburg, turned this policy into an object of competition between the SPD and the Greens. However, this competition was subsequently displaced once the programmes of conservative regional and federal governments at the end of the 1980s took socioculture into account. Certainly, this integration constituted a new opportunity for sociocultural animation, but at the same time it unhooked this animation from its activist networks as it based itself above all on criteria of professional competence.

The initiative for the creation in the FRG of alternative sites of culture came in over a third of cases from citizens' movements and in over half of the cases from individuals; administrative bodies seem to have occupied a marginal role in the organisation of socioculture $(5.5 \%)$ and to have left all the initiative in this domain to 'civil society' (see Hussmann's survey, 1992). Nevertheless, once they had been set up, these district and local centres generally found themselves under the authority of municipal councils as far as the supervision of installations and the permanent employment of social workers were concerned.

Secondly, on the basis of these once activist and subsequently municipal practices, a new sector of intervention was constituted and recognised through the setting up of sites where it could be formalised, public forums constituted by the different specialists and practitioners involved. It was in this way that, despite conflicting representations of their cultural objectives, the different agents of cultural policy managed to establish a compromise through the construction of a common language.

The harmonisation and diffusion of this new model of public action were developed principally in the FRG through the framework of the Council of German Cities, a national pressure group representing municipal councils before the regional and federal governments. Its new strategic orientations of 1973 and the institutional launch of socioculture were the achievements of a group of critical intellectuals from the SPD (or close to this party) engaged in the implementation of municipal policies. In France, several bodies played a similar role: the Socialist Party's Culture Office created in 1974, groupings of elected politicians (the FNCC and FNESR), federations issuing from the popular education movement (Léo-Lagrange Clubs, Houses for Youth and Culture, etc.), or again the sites for the training of animateurs (the CFNA, INJEP, and ADRAC...) as well as reviews (Cahiers de l'animation, Pour, Silex...). ${ }^{\mathrm{vi}}$

This transition from informal practices to municipal policies therefore brought with it a professionalisation of sociocultural activities. The transition from volunteers to salaried 
workers in these domains resulted in France, and to a lesser extent in the FRG, in a professionalisation of work previously carried out by activists and its transformation into specific types of activity paving the way for new kinds of professional logic. The processes of institutionalisation and professionalisation of cultural action were marked at the end of the 1970s, as much in France as in the FRG, by the intervention of new categories of agents in the social treatment of culture, who progressively took the place of the representatives of the community and activist networks. Once public action took over from voluntary action, and once the latter tended to be converted into professional specialisation, the management of issues became a technical matter requiring their conceptualisation in formal terms by experts - thereby becoming effectively a delocalized form of management. This transition from voluntary worker to professional, from human qualities (the ability to relate to people, 'charisma', etc.) to technical skills is described as an experience of being torn between two poles in the abundant literature on the 'profession of animateur', which stresses more or less critically the difficulties of reconciling a politically based (in the broad sense of the term) personal engagement and the attributes required by the specialist seeking professional recognition. .ii $^{2}$

Institutionalisation and relegation

The institutionalisation of a sociocultural sector did thus not take place without contradictions. Furthermore, whereas the voluntary activism characterising the sociocultural constellation helped local cultural policies to emerge, the institutionalisation of these policies and their 'cultural' specification, the specialisation of the structures and of the agents implementing them led to a sidelining of the agents and discourses of the 'sociocultural' domain, which had become the residue of a henceforth illegitimate inheritance.

The specification of cultural policies detached from the adjacent sectors of animation or leisure, autonomous with regard to the social networks that contributed to their emergence, and equipped with specific rules and norms, led to a considerable transformation of the position they occupied in the space of local society.

The process of professionalisation which characterised them meant that, over the course of their development, a whole series of social agents were sidelined (amateurs, voluntary workers, community activists, trade unionists, social workers, even politicians) who previously could have taken part in discussions. The principle of cultural delegation was thereby transformed: the agents authorised to speak of culture in the name of the social group were no longer those who through their voluntary commitment or political acitivity had been assigned representative functions, but rather those who could boast of a specialised competence, guaranteed by the fact that they belonged to the world of the professionals.

It is therefore understandable that local cultural policies, after a period of intense politicisation, might appear as depoliticised: those who were defining them had managed to win their autonomy with regard to elected politicians, but also with regard to politically constituted networks of support (politically partisan networks, or the post-1968 movement in France, for example).

It is equally understandable that this process was accompanied by a process of 'delocalisation'. Agents engaged in cultural matters had previously been predisposed by the position they occupied to invest in and valorize local matters (elected politicians 'close to the people' and more generally on the political left, community activists issuing from the middle classes). This state of affairs was succeeded by the invention of professional positions, whose success implied the sidelining of both local attachments and also references to heteronomous discourses (political ideologies, and principles inherited from other social spaces, such as 
that of social work). The tendency that has often been observed for municipal cultural policies to become standardized is one of the indicators of this delocalisation - itself induced by the growing importance of norms defined in a nationally constituted professional milieu for the elaboration of these policies.

Finally, it is understandable that all this has been accompanied by what one could call the 'de-socialisation' of local cultural policies. These policies had originally been constituted partly on the basis of collective mobilisations and around 'social' objectives; they tended over the 1980s and 1990s to become a matter for 'specialists' who proclaimed their political and social neutrality by invoking cultural excellence, and who were predisposed to assert specifically cultural objectives (the democratisation of culture, aid for contemporary creation, etc.) to the detriment of more 'social' objectives that were left to the specialists of the sector for social action.

\section{THE REINVENTION OF A 'SOCIAL’ ROLE}

While over the 1980s, references to the social aspects of cultural animation were progressively eclipsed by other logics and agents (those of cultivated culture, the field of the media, economic interests, etc.), it seems that we have been seeing increasingly over recent years the reemergence of properly social objectives for the public treatment of culture. ${ }^{\text {viii }}$ This reemergence has been particularly strong in France in working-class suburban zones, and in the Federal Republic of Germany in the context of unification, where the integration of the East German population raises likewise the problem of the 'social' integration of certain marginalised social categories.

In France, since the end of the 1980s, this reemergence has given rise, for example, to the invention of new and diverse cultural and institutional forms, such as the public commissioning of contemporary works of art designed to 'restructure urban space' and to 'revitalise the democratic debate'; the setting up of writing workshops for young people experiencing difficulties; cultural support and legitmation for practices deemed specific to suburban areas, such as rap or graffiti; the sometimes very 'cultural' tone of regeneration projects developed in the framework of urban policy (contracts issuing from the urban social development unit (DSQ) and from the unit for the social development of urban districts (DSQ)), etc. In the former East Germany, it is a question more generally of valorising initiative, the 'apprenticeship' of individual autonomy and freedom of expression, and thus of implanting and transferring a tried and tested form of democratic culture (see Laborier, 1996a). Here, the federal public funds attributed to socioculture in the new regions partially take up again the explicit principles of the first institutions from the years 1975 to 1979 , assigning themselves as objectives the intitiation of people into the social forms of political work and democratic culture, and the development of a culture of resistance against 'fascist forces'. Nevertheless, it is no longer a question in this context of mixing together different age-groups, social origins or nationalities, but rather of integrating German populations into the West German model.

This reemergence of references to the social context in local cultural action only appears to represent a return. For this 'return to the social context' assumes different forms to those prevalent over the first period, due to the presence of new types of agents, who are the bearers of different types of discourse and logic. It follows principally two paths that are contradictory as far as the 'cultural theory' underpinning them is concerned (cf. Passeron, 1991), but which are often mixed up in practice. The first path forms part of the movement aiming at the 'cultural rehabilitation' of socially disadvantaged populations, developed especially over the period of the second Lang administration (1988-1993). This cultural 
labelling consists in an ethnographic and/or aesthetic treatment (i.e., in both cases, conforming to the criteria of professional expertise) of practices that are external to the universe of consecrated culture, and indeed socially stigmatized. ${ }^{\text {ix }}$ The second path of the 'return to the social context' consists in the intervention of professional and recognised artists in 'difficult zones'. The case of public art has already been evoked, and one could add the funding of artists in residence in working-class districts, or again the staging of performances by theatre directors or choreographers in partnership with the local population. These practices can sometimes seem very close to two formerly prevalent and symmetrically opposed orientations. However, at least in rhetorical terms, they aspire to distinguish themselves from these, denying their proximity to classical cultural proselytism by stressing how they organise the capacity of the relevant social groups to voice their concerns in a cultural perspective, and denying their proximity to old-style sociocultural animation by stressing the reference to 'creation' and the intervention of professional artists.

The reaffirmation of the necessary 'social' anchoring of cultural policies (i.e. their mobilisation in the treatment of social problems) is thus not an identical repetition of the practices of the 1960s and 1970s which, after their relegation, have thereby been in part 'recycled', $\mathrm{x}$ and hence partially integrated into the invention of new forms. This recycling is indeed partial: in France especially, sociocultural animation continues to act largely as a foil, even - and perhaps especially - for those cultural professionals who have invested most in 'social' issues.

What, then, are the principal logics governing this 'return to the social context' in local cultural policies? We would like to propose two hypotheses here, which by no means exclude others. The first hypothesis concerns the link between this 'return to the social context' and the budget constraints weighing on cultural policies, which appear to exert opposite effects in the two countries. In the FRG, after a period of relative consensus, it is budgetary pressure that has brought Soziokultur back on the agenda, and it is denounced again as representing a bad use of public funds and is thus designated as a prime sector for cuts in the culture budgets. The reduction of sums allocated to culture seems to point more in the direction of a 'social' reclassification of cultural expenditure. It is all as if, since the argmument of 'cultural democratisation' now appears dated and the budgets are under threat, new types of 'investments in appearance' ${ }^{\mathrm{xi}}$ had to be agreed that could provide justifications for funding in line with the political priorities proclaimed both locally and nationally of the 'struggle against social exclusion' and the 'reduction of social division'. One should not fall prey to the cynical view that activities are simply being 'dressed up' in social terms for self-serving ends, for the current conditions are no doubt likewise ripe for reactivating the belief among cultural professionals in the re-socialising virtues of their activities.

Nevertheless, it is conceivable that many projects of so-called social 'requalification' through culture (in the sense of rehabilitation) correspond also to a recategorisation in 'social' terms of cultural interventions translated into and reproblematised through the perspective of the 'struggle against social exclusion' and the restoration of the 'social bond'.

The second hypothesis concerns inverse movements between local and national levels in the two countries. In the FRG, Soziokultur, initially invented in a period of intense politicisation thanks to the emergence of the Greens as a political force, and then relayed by left-wing municipal councils, was by the end of the 1980s and the beginning of the 1990s accepted even by conservatives as a legitimate component of cultural policy. Thanks to reunification, the assertion of the necessary social anchoring of cultural policies would finally become part of a national discourse. In France, one sees in some ways a movement in the opposite direction. The process of professionalisation evoked above, and with it the relegation of the 'sociocultural' domain, are largely the product of national policies initiated at the beginning of the $1980 \mathrm{~s}$. The same is the case for the 'return to the social context' that takes 
place locally, not through some kind of revenge on the part of 1970s activists and animateurs, but to a great extent in conformity with the norms of the national model of professionalised cultural policies.

The attribution of social objectives - in the sens of social policies - to the public financing of culture is thus also a function of the relations between the different levels of public intervention - the local and the national levels in France, and the municipalities, regions and federal State in Germany. The differences between these sets of relations in the two countries helps explain the differences between the forms assumed by the 'return to the social context'. This rediscovery also goes beyond the national framework; it has become, so it seems, a norm at the European level.

Germany and France are not the only countries in Europe to have witnessed such an evolution. In Italy, public investment in culture has often been presented as useful in the struggle against unemployment, and in Ireland or Great Britain, it has been integrated partially into programmes of so-called social cohesion. As was the case in the 1970s around the notion of sociocultural animation in cities, an international institution such as the Council of Europe tends today to highlight in its programmes and meetings the need for a cultural dimension in projects of social integration, particularly in disadvantaged urban areas. The 'struggle against social exclusion' is a topic for debate and the exchange of experiences among the networks of cultural professionals. ${ }^{\text {xii }}$ Finally, the attribution of social policy objectives to the public financing of culture takes place especially at the level of the European Community, for several reasons. Firstly, the relative weakness up until now of European Union programmes for culture has led to funding for cultural projects to be sought via programmes with a 'social' dimension (such as PHARE, or URBAN) and, consequently, to the 'social' recategorization of these projects. Secondly, the resistance of representatives of several member States - in particular Great Britain - to the assertion of a European Union role in the cultural domain has made it necessary to resort to other than specifically cultural arguments to legimate the development of interventions in this domain. These have included arguments based on the promotion of European identity, support for development of the tourist industry and thus of the economy as a whole, or equally the notion of a 'social cohesion' strengthened through culture.

Translated by Jeremy Ahearne

\section{REFERENCES}

Balme, R. (1987), La participation aux associations et le pouvoir municipal. Capacités et limites de mobilisation par les associations culturelles dans les communes de banlieue, Revue française de sociologie, 27 (4).

Bédarida, C. (1996), Les institutions culturelles, remèdes aux violences urbaines. Le Monde, 16 November.

Besnard, P. (1980), Animateur socioculturel: une profession différente?, Paris: ESF.

Dubois, V. (1993), Politiques culturelles et politiques médiatiques, Politix, 24.

Dubois, V. (1994), La culture comme catégorie d'intervention publique. Genèses et mise en forme d'une politique, Lyon: Institut d'études politiques [thesis].

Dubois, V. (1994a), Action culturelle/action sociale, les limites d'une frontière. Revue 
française des affaires sociales, April-June 1994.

Dubois, V. (1995), Pour la culture ou contre l'Etat? La FNCCC et l'institutionnalisation des politiques culturelles au début des années soixante, in Jalons pour l'histoire des politiques culturelles locales, Paris: La Documentation française.

Dubois, V. (1999), La politique culturelle. Genèse d'une catégorie d'intervention publique, n.p.: Editions Belin.

Gaudibert, P. (1972), Action culturelle, intégration et/ou subversion, Paris: Casterman.

Gaxie, D. (1997), Remarques sur le comparatisme, le franco-centrisme et quelques autres sujets topiques, Palaestra, 3 (9).

Gray, C. (1996), Comparing cultural policy: a reformulation, European Journal of Cultural Policy, 2 (2).

Hussmann, U. (1992), Soziokulturelle Zentren in der Bundesrepublik, in Sievers, N. \& Wagner, B. (eds), Bestandsaufnahme Soziokultur. Beiträge, Analysen, Konzepte, Stuttgart: Kohlhammer.

Hussmann, U., Steinert, T. (eds) (1990), Vielfalt als Konzeption. Zu der Arbeit der soziokulturellen Zentren und den Anforderungen an ihre Mitarbeiter, Bonn: BMBW.

Ion, J. (1982), Les animateurs socioculturels en France. Limites d'une problématique de la professionalisation, Loisirs et Société, 5 (1).

Laborier, P. (1996), Culture et édification nationale en Allemagne. Genèse des politiques de la culture, Paris: Institut d'études politiques [thesis]

Laborier, P. (1996a), Conservation ou rénovation? Transitions de la politique culturelle. Politix, 33.

Laborier, P. (1998), La Soziokultur en RFA, in Dubois (ed.), Politiques locales et enjeux culturels: les clochers d'une querelle, Paris: La Documentation française.

Lambert, B., Matonti, F. (1998), Les forains légitimes, in Dubois (ed.), Politiques locales et enjeux culturels: les clochers d'une querelle, Paris: La Documentation française.

Lascoumes, P. (1994), L'éco-pouvoir, environnement et politiques, Paris: La Découverte.

Liebald, C. (1992), Kulturarbeit in sozialen Felden, in Sievers, N. \& Wagner, B. (eds), Bestandsaufnahme Soziokultur. Beiträge, Analysen, Konzepte, Stuttgart: Kohlhammer.

Monsaingeon, G. (1997), Un ministère pour la culture? L'Italie entre traumatisme, tutelle et tentation, Le Débat, 1997.

Moulinier, P. (1980), La formation des animateurs culturels, Paris: Unesco.

Passeron, J.-C. (1991), 'Figures et contestation de la culture', in Le Raisonnement sociologique, Paris: Nathan.

Pinçon, M., Pinçon-Charlot, M. (1985), Classes moyennes, enjeux culturels et trajectoires sociales, Les Cahiers de l'animation, 53.

Pongy, M., Saez, G. (1994), Politiques culturelles et régions en Europe, Paris: Harmattan.

Poujol, G. (1974), Le métier d'animateur, Toulouse: Privat.

Rigaud, J. (1995), L'exception française. Culture et pouvoirs publics sous la Cinquième République, Paris: Grasset.

Saez, G. (1981), Vers un mode d'être 'culturel local'?, Pour, 77.

Schulze, G. (1993), Die Erlebnisgesellschaft. Kultursoziologie der Gegenwart, Frankfurt am Main: Campus.

Simonot, M. (1974), Les animateurs socioculturels. Etude d'une aspiration à une activité sociale, Paris: PUF.

Simonot, M. (1981), Les couches moyennes au pouvoir: le cas de Louviers, Pour, 77.

Thévenot, L., (1986), 'Les investissement de forme', in Conventions économiques, Paris: CEE-PUF, pp. 21-71.

Urfalino, P. (1994), L'échec d'une contre-politique culturelle. La FNCCC, in L'Art de la recherche. Essais en l'honneur de Raymonde Moulin, Paris: La Documentation 


\section{française.}

\footnotetext{
i See e.g. Rigaud (1995). For an overview of these debates, see Dubois (1993).

ii This was the case notably in Italy during the debates over 1995 and 1996 concerning the establishment of a 'French-style' Ministry of Culture (see Monsaingeon, 1997). The reference to the French case was also present when the regional government of Baden-Württemberg wanted in 1990 to unify responsibilities that were 'dispersed' among five ministries under the authority of a grand regional ministry for culture (see Pongy and Saez, 1994). The reference to the 'French model' was also present to a lesser degree during the debates associated with the creation of a British Department of National Heritage in 1992, and subsequently with the creation of a Department for Culture, Media and Sport in 1997.

iii This comparative sketch is based on studies which originally had no directly comparative aim (see Dubois, 1994 and 1999; Laborier, 1996). These empirical studies allowed us to adopt together a comparative perspective that looks to pay heed to the salutary warning and the propositions recently put forward by D. Gaxie, 1997. iv See e.g. Pinçon and Pinçon-Charlot, 1985; Saez, 1981; Simonot, 1981; Schulze, 1993. For a sociological analysis of the mobilisations through associations characterizing these 'middle classes' in the cultural domain, see Balme, 1987.

v [Translator's note: on post-war popular education groups, see Brian Rigby, Popular Culture in Modern France, London, Routledge, 1991, pp. 39-67]

vi [Translator's note: the FNCC stands for the National Federation of Communes for Culture; the FNESR for the National Federation of Socialist and Republican Politicians; the CFNA for the National Centre for the Training of Animateurs; the INJEP for the National Institute for Youth and Popular Education; and the ADRAC for the Association for the Development of Reaearch on Cultural Action]

vii See e.g. Besnard, 1980; Ion, 1982; Moulinier, 1980; Poujol, 1978; Simonot, 1974; Liebald, 1992; Hussmann and Steinert, 1990.

viii For a partial survey of cultural projects structured around the 'struggle against social exclusion' in France, see e.g. 'La culture pour s'en sortir', Télérama, hors série, January 1996. One should add certain programmes of the Ministry of Culture, notably after 1995, such as those targetting 22 'difficult' suburban districts. See 'L'an II des projets culturels de quartiers', Policultures: la lettre des politiques culturelles et artistiques, 15, April 1997; 'Projets culturels de quartier: premier bilan', Lettre d'information du ministère de la Culture, 2, 29 janvier 1997.

ix For a case-study, see Dubois, 1994a.

$\mathrm{x}$ The expression is from Lascoumes, 1994.

${ }^{x i}$ Investissements de forme - see Thévenot, 1986.

xii One might cite, for example, the network of European suburbs, that has been based around the Laiterie in Strasbourg, and that is designed to valorise the cultural experiences of working-class districts; or, more punctualy, the meeting on 21-22 October 1996 at La Villette of representatives from 16 cultural institutions in different countries, who came together to debate the responses of cultural spaces to problems associated with unemployment, poverty and delinquency (see Bedarida, 1996).
} 